\title{
Party autonomy in international family relationships : a research agenda Patrick Wautelet ${ }^{*}$
}

1. In recent years, there has been quite a lively debate on choice of legal regime by citizens ${ }^{1}$. The debate has focused on concepts such as empowerment, enhancing participation of citizens in the European integration process and other items ${ }^{2}$. For once, private international law may have something to say in the discussion. The idea of choice by citizen indeed nicely fits in one of the cornerstones of modern private international law, i.e. the concept of party autonomy ${ }^{3}$. This mechanism is well known in the field of cross-border contracts. Parties to such contracts may select which law governs their contract, as has recently been confirmed by the Rome I Regulation whose Preamble indicates that the parties' freedom to choose the applicable law "should be one of the cornerstones of the system of conflict-of-law rules in matters of contractual obligations" 4 . The nature, effects and consequences of such choice have been studied, against a background of intense debate on the legitimacy of allowing parties to choose the law applicable to their contract ${ }^{5}$.

More recently, party autonomy has conquered new grounds in cross-border private relationships ${ }^{6}$. Building on first attempts in national codifications ${ }^{7}$, party autonomy has become one of the leading principles used in various EU regulations dealing with cross-border family relationships. It can now be found in successions $^{8}$, in divorce ${ }^{9}$, in maintenance matters ${ }^{10}$. It is widely expected that the future Regulation dealing with matrimonial property regimes will also allow parties to choose the applicable law ${ }^{11}$. This new trend has been greeted

* Patrick Wautelet is Professor of Private International Law at the University of Liège, email : patrick.wautelet@ulg.ac.be. This contribution is based on a talk delivered at the conference 'The Citizen in European Private Law : Norm-setting, Enforcement and Choice', held at Maastricht University on 18 October 2013.

1 See e.g. the papers published in Autonomie en droit européen? Stratégie des citoyens, des entreprises et des Etats, C. KESSEDJIAN (ed.), Ed Panthéon-Assas, 2013.

2 See e.g. J. SMITS,” Beyond Euroscepticism : on the choice of legal regimes as empowerment of citizens”, Utrecht Law Rev., vol. 6/3, 2010, pp. 68-74.

3 The link between choice in general and party autonomy in private international law, is made by J. SMITS, op. cit., 70 .

4 Recital 11. The Court of Justice has confirmed the central role of party autonomy in its Unamar ruling : ECJ, 17 October 2013, case C-184/12, United Antwerp Maritime Agencies (Unamar) NVv Navigation Maritime Bulgare, par. 49.

5 See J.-M. JACQUET, "La théorie de l'autonomie de la volonté”, in Le Règlement communautaire 'Rome I' et le choix de loi dans les contrats internationaux, S. CORNELOUP and N. Joubert, Litec, 2011, pp. 1-15; CH. KOHLER, L'autonomie de la volonté en droit international privé : un principe universel entre libéralisme et étatisme, ADIpoche, 2013, 155-262. For a recent attempt to question the foundations of party autonomy see H. MUIR WATT, "'Party Autonomy' in International Contracts: From the Makings of a Myth to the Requirements of Global Governance”, Eur. Rev. Contract L., 2010, 1-34.

6 Another area where party autonomy has also been considered, is that of property law. Even though scholars have convincingly pleaded for the introduction of party autonomy in this field (see e.g. R. WESTRIK and J. VAN DER WEIDE, Party autonomy in international property law, Sellier, 2011, 276 p. See already A. FLESSNER, "Rechtswahl im internationalen Sachenrecht - neue Anstösse aus Europa”, in Festschrift für Helmut Koziol zum 70. Geburtstag, P. APATHY et al. (eds.), Vienna, 2010, 125-146), not much progress has been made so far. More recently, a plea has been made to allow party autonomy in intellectual property issues, see R. MATULIONYTE, "Calling for Party Autonomy in Intellectual Property Infringement Cases”, J. Priv. Intl. L., 2013, 77-99.

7 Most notably the Dutch Act dealing with cross-border divorces, adopted in 1981 : Article 1 par. 4 of the 'Wet houdende regeling van het conflictenrecht inzake ontbinding van het huwelijk en scheiding van tafel en bed...' adopted on 25 March 1981 allowed the spouses to make a choice for the application of Dutch law.

8 Article 22 of Regulation 650/2012.

9 Article 5 of Regulation 1259/2010.

10 Article 15 of Regulation 4/2009, which refers to the 2007 Hague Maintenance Protocol.

11 And may also one day be accepted in matters of name, see the proposal made by A. DUTTA, R. FRANK, R. FREITAG, 
2. While these Regulations constrain the choice that parties can make, it cannot be denied that the principle of freedom of choice has been openly embraced by the European legislator. Hence this principle evolved, at least within the EU, from what was until recently a marginal phenomenon to a wellrespected solution for cross-border family relationships This ( $r$-)evolution occurred quite fast and has attracted much attention. However, much of the research in this area has adopted a limited perspective, focusing exclusively on the possibilities and limits of choice in one specific instrument ${ }^{13}$ or adopting a comprehensive outlook but with a strong positive flavor ${ }^{14}$. While it is true that a number of contributions provide excellent food for thought ${ }^{15}$, the overall impression is that more time and more research is needed to start apprehending the fundamental questions raised by this evolution ${ }^{16}$. This may be due in part to the relative novelty of party autonomy in international family relationships ${ }^{17}$. It may also be due to the unavoidable tendency to look for inspiration to the field of cross-border contracts, where party autonomy can claim a much longer history. There is indeed a clear genealogy of rules which can be traced to the Rome I Regulation and previous instruments dealing with cross-border contracts.

T. HeLmS, K. KRÖMER and W. PINTENS, 'Ein Nam in ganz Europa. Entwurf eine Europäischen Verordenung über internationale Namensrecht', StAZ 2014, 33-44.

12 E.g. B. Bourdelois, 'Relations familiales et professio iuris', Mélanges en l'honneur du Professeur Bernard Audit. Les relations privées internationales, LGDJ/Lextenso, 2014, 137-154.

13 Such as the role of party autonomy in the area of cross-border maintenance claims (see e.g. V. LiPP, 'Parteiautonomie im internationalen Unterhaltsrecht', in Confronting the frontiers of family and succession law : liber amicorum Walter Pintens, vol. 1, Intersentia, 2012, pp. 847-866), of cross-border divorce (see e.g. A. RÖTHEL, 'Rom III-VO : Impulse für eine Materialisierung der Parteiautonomie', in Europäische Einflüsse auf den deutsch-italienischen Rechtsverkehr, Müller, 2013, pp. 3-15), of succession matters (see e.g. C. CACH and A. WEBER, 'Privatautonomie im Internationalen Erbrecht : Überlegungen zu Art 22 der Europäischen Erbrechtsverordnung', ZfRV, 2013, pp. 263-269 (studying choice of law in succession matters) or cross-border matrimonial property regimes (see e.g. M. CH. SotiRopoulou, 'The option given to spouses to choose the applicable law defined in the Proposal for a Council Regulation on jurisdiction, applicable law and the recognition and enforcement of defisions in matters of matrimonial property regimes : progress or not?', 66 Revue hellénique de droit international, 2013, 21-38).

14 See e.g. D. HeInRICH, 'Zur Parteiautonomie im europäisierten internationalen Familienrecht', in Confronting the frontiers of family and succession law : liber amicorum Walter Pintens, vol. 1, Intersentia, 2012, pp. 701-713.

15 See e.g. the various contributions published in NIPR 2012/4 (M. HoOK, 'Party Autonomy - Yes or No ? The 'Commodification' of the Law Applicable to Matrimonial Property Relationships', NIPR, 2012, pp. 587-596; M. TORGA, 'Party Autonomy of the Spouses under the Rome III Regulation in Estonia : can Private International Law change Substantive Law ?', NIPR, 2012, pp. 547-554; I. ViARENGO, 'The Role of Party Autonomy in Cross-Border Divorces', NIPR, 2012, pp. 555-561; S. PEARI, 'Choice-of-Law in Family Law : Kant, Savigny and the Parties' Autonomy Principle', NIPR, 2012, pp. 597-604 and C. IstVAn NAGY, 'What Functions may party Autonomy have in International Family and Succession Law? An EU Perspective', NIPR, 2012, pp. 576-586). Adde B. ANOvEROS TERRADAS, « La autonomia de la voluntad como principio rector de las normas de Derecho internacional privado comunitario de la familia », in Entre Bruselas y La Haye : estudios sobre la unificacion internacional y regional del Derecho interncional privado. Liber Amicorum Alegria Borras, J. Forner DeLAYGuA et al. (eds.), Marcial Pons, 2013, 119-131 and J. M. CARRUTHERS, «Party Autonomy in the Legal Regulation of Adult Relationships : What Place for Party Choice in Private International Law », ICLQ, 2012, pp. 881-913.

16 It is notable that in two recent fundamental papers on party autonomy, leading scholars have almost exclusively focused on the use of party autonomy in contracts - see e.g. M. LEHMANN, 'Liberating the Individual from Battles between States : Justifying Party Autonomy in Conflict of Laws', Vanderbilt J. Transnatl. L., 2008, 381-434 and J. BAsEDOW, 'Theorie der Rechtswahl oder Parteiautonomie als Grundlage des internationalen Privatrechts', RabelsZ., 2011, 32-59.

17 The issue is not entirely novel. In the past, some scholars have already devoted quite some attention to the issue of party autonomy in family law. See most notably J.-Y. CARLIER, Autonomie de la volonté et statut personnel. Etude prospective de droit international privé, Bruylant, 1992, 468 p. and P. GANNAGÉ, 'La pénétration de l'autonomie de la volonté dans le droit international privé de la famille', Rev. crit. dr. int.priv., 1992, 424-454. While very inspiring, these two contributions could not a the time refer to positive recognition of party autonomy in cross-border family relationships. 
This 'copy-paste' attitude which can be found both in legislative acts and in scholarship, does not do justice to the peculiarities of party autonomy in crossborder family relationships.

3. At this stage, it may be too early to offer a comprehensive study of all questions raised by party autonomy in private international law. New developments may in fact modify the picture soon and add to the fields conquered by party autonomy. At the same time, the relative novelty of the changes makes it difficult to take full stock of all issues raised by the development of party autonomy. This is why scholars should first attempt to define a research agenda. This paper offers a first scratch by exploring various questions which should figure prominently in such agenda. It is by no means meant to be exhaustive. Rather, an attempt will be made to shed some light on the main questions raised by recent evolutions in the hope of being an invitation for further research.

\section{Section 1 Mapping out party autonomy}

4. A first item on the research agenda should be to map out the extent and limits of party autonomy under the current private international law regulations.

It will be fairly easy to describe all opportunities for choice existing under the various Regulations adopted by the EU. In fact, such work has already been undertaken. A comprehensive mapping should, however, also include a comparison of the differences existing between the European instruments. To give but one example : under the Succession Regulation, one may choose to subject its succession to the law of its nationality. In the absence of an express provision to that effect, Article 22 par. 2 makes it possible to infer a choice of law from the "terms" of a disposition of property upon death. Hence, it may be possible to find out that a person has chosen a law even though such choice has not been expressly stated ${ }^{18}$. By contrast, it is unclear whether such an implicit choice of law may be accepted under the Rome III Regulation. While some commentators have argued that the terms of the Regulation may accommodate an implicit choice of law, ${ }^{19}$. It has also been suggested that the Regulation leaves no room for such choice ${ }^{20}$. Other differences may exist between the Regulations, which should be thoroughly analyzed.

5. Going beyond choice possibilities offered by Regulations and other EU instruments, research should also extend to less visible forms of party autonomy. Indirect choice possibilities have always existed. To refer to one traditional example : in a not so distant past, some couples traveled to Scotland to get married or to Nevada to obtain a divorce, both of which would have been very difficult to obtain in their home jurisdiction ${ }^{21}$. In some regions of the world,

18 See the explanations of A. Bonomi in Le droit européen des successions. Commentaire du Règlement $n^{\circ}$ 650/2012 du 4 juillet 2012, A. BONOMI and P. WAUTELET, Bruylant, 2013, pp. 321-325.

19 See e.g. A. Devers and M. FARge, "Le nouveau droit international privé du divorce - À propos du règlement Rome III sur la loi applicable au divorce”, Dr. fam., 2012, étude 13, nr. 17).

20 T. AzZI, « La volonté tacite en droit international privé », Trav. comité français DIP 2010-2012, Pedone, 2013, 147177, at p. 165.

21 See the account by V. vAN POPPEL, 'Wetsontduiking bij clandestiene huwelijken', Tijdschrift voor Privaatrecht, 1968, 427-457. On marriages celebrated in Gretna Green, see e.g. CA Brussels, 17 January 1962, Pasicrisie, 1963, II, 30. 
such marriage tourism is still alive and kicking, with couples willing to get married sometimes traveling to neighboring countries to avoid having to comply to what it perceived as cumbersome requirements ${ }^{22}$. More recently, the advent of registered partnerships and same-sex marriages in some jurisdictions may have encouraged some form of legal tourism. This may have been especially noticeable in jurisdictions which did not impose strict jurisdictional requirements to access such legal status ${ }^{23}$. It may also have been encouraged by the special treatment afforded under private international law to same sex marriages ${ }^{24}$. These forms of legal tourism come very close to strategies of legal engineering. They do not arise out of direct recognition of party autonomy. At the end of the day, this phenomenon comes, however, very close to a choice by the parties concerned of their legal status. They should therefore also be taken into account when discussing the role and limits of party autonomy.

Many of the instruments adopted by the EU to deal with cross-border situations also afford the parties a measure of choice, even if only indirectly. This is in the first place the case when rules of jurisdiction make it possible for a plaintiff to select between a number of jurisdictions. The EU has adopted a number of uniform rules of jurisdiction in private law. These apply among other fields in contract, liability in tort but also divorce and maintenance matters. What is striking with these rules, is that they often offer the possibility to select out of two (or more) courts. If a car accident occurs, say, in Maastricht between a Dutch national riding a bike and a car with a Belgian license plate, the injured biker may bring proceedings either in Netherlands ${ }^{25}$ or in Belgium ${ }^{26}$. He has in other words a choice between two courts. This choice has in turn been made easier because wherever he chooses to bring proceedings, he may be certain that the judgment will be recognized in other Member States ${ }^{27}$. The same may be said when one spouse wants to file for divorce : under Article 3 of the Brussels Ilbis Regulation, there will often be a choice between several jurisdictions.

Such a choice possibility may be less apparent than an outright possibility to choose the law enshrined in an explicit provision to that effect. It does not have

22 Some Danish islands attract many couples living in Germany and wishing to get married, see 'Marriage migration makes Denmark 'Europe's Las Vegas' - Lenient laws for marrying bi-national couples makes Denmark a haven for Germans and their foreign fiancees', The Copenhagen Post , October 12, 2012 (http://cphpost.dk/news/marriagemigration-makes-denmark-europes-las-vegas.3031.html ).

23 For the situation in Germany, see D. MARTINY, "Private international law aspects of same-sex couples under German law", in Legal Recognition of Same-Sex Relationships in Europe. National, Cross-border and European Perspectives, K. BOELE-WoELKI \& A. FuCHS (eds.), Intersentia, 2012, at p. 190.

24 For various reasons, States allowing same sex marriages have indeed made it easier for couples to marry, by bringing nuances to the application of the national law of the future spouses. In Belgium, Article 46 of the Code of Private International Law makes to possible to disregard the fact that under the national law of one of the spouses, a marriage would not be possible because of the fact that the two spouses share the same sex. According to Verhellen, this caveat to the application of the national law of the spouses has been frequently applied (J. VerHELLEN, "Lost in Nationality : Private International Law and Cultural Diversity", in Approches juridiques de la diversité culturelle, M.-CL. FoBlETS \& N. YASSARI (eds.), Martinus Nijhoff, 2013, (521), 561, n 74). In France, a similar provision has been adopted - see article 202 of the French Civil Code, as modified by the Act N) 2013-404 of 17 May 2013 "ouvrant le mariage aux couples de personnes de même sexe".

25 Article 7(2) Brussels Ibis Regulation (recast).

26 Article 4 Brussels Ibis Regulation (recast).

27 According to Article 39 of the Brussels Ibis Regulation (recast), "A judgment given in a Member State which is enforceable in that Member State shall be enforceable in the other Member States without any declaration of enforceability being required. ”. 
the same, radical effects as a choice for the law of one State ${ }^{28}$. However, by choosing the court, a plaintiff exercises a great impact on the conduct of litigation. Such choice possibility, which is built in the system, should therefore not be underestimated.

6. In recent years, important evolutions in case law, in particular case law of the ECJ, have also expanded the possibility for parties to exercise an 'indirect' choice in certain contexts. This is particularly the case for the consequences of the European treatment of multiples nationals. Dual nationals have always been a challenge for private international law. Special rules have been developed to allow the application of conflict rules in case the person concerned possesses more than one nationality ${ }^{29}$.

One striking feature of the recent developments of EU law is that the ECJ has issued strict guidelines on how Member States should handle cases of multiple nationalities : to put it briefly, Member States no longer have the freedom to consider that a person who possesses two nationalities among which their nationality, is only one of their nationals. There is a set of rules, which constrain how Member States should view multiple nationalities ${ }^{30}$. The ECJ has even touched on cases involving the nationality of a third State, suggesting that Member States should also in this respect forgo their traditional rules in order to let the persons concerned enjoy the benefits of the nationality of their choice ${ }^{31}$.

A consequence of these guidelines is that the persons having more than one nationality may end up with a possibility to choose the nationality on which they rely. This was manifestly the case in the Garcia Avello case : the parents of the two children born in Belgium first relied on their two children being Belgian citizens (which opened the possibility to request a change from Belgian authorities under local law). Subsequently, they challenged the refusal by Belgian authorities to allow the change of name relying on the fact that their daughters were not only Belgian nationals, but also Spanish nationals.

The sequels of Garcia Avello in Belgium make it very clear that this case gives some choice to parties : for children born in Belgium with two nationalities, one EU and the other Belgian there is now an (informal) choice granted to the

28 This is in particular the case since account should be taken of the fact that the EU has also adopted uniform rules of conflict of laws which in many fields, reduce the importance of the choice between several jurisdictions. This is the case in matters of tortious liability (Rome II Regulation) and divorce proceedings (Rome III Regulation).

29 Another question arises in relation to the exercise of party autonomy by dual nationals, i.e. whethere the general rules dealing with cases of multiple nationalities (see in general M. VerWILGHEN, 'Conflits de nationalités : plurinationalité et apatridie', Collected Courses of the Hague Academy of International Law, volume 277, 1999, pp. 9-484) must be applied when party autonomy is recognized in instruments of private international law. See on this issue, T. Kruger and J. Verhellen, 'Dual Nationality = Dual Trouble?', J. Priv. Intl. L., 2011, vol. 7/3, (601), at p. 618-619.

30 This follows from a series of cases, among which ECJ, 7 July 1992, Micheletti and others $v$ Delegacion del Gobierno en Cantabria, case C-369/90, ECR 1992, I-4239; ECJ, 16 July 2009, Laszlo Hadadi v Csilla Marta Mesko, case C-168/08, ECR 2009, I-6871 and ECJ, 2 October 2003, Carlos Garcia Avello v Belgian State, case C-148/02, ECR, 2003, I-11613.

31 See e.g. ECJ, 29 March 2012, Staatssecretaris van Justitie v Tayfun Kahveci and Osman Inan, cases C-7/10 and C9/10. The Court held that a particular provision of a decision adopted in the framework of the Association Agreement concluded between Turkey and the Eu should be interpreted as meaning that "the members of the family of a Turkish worker duly registered as belonging to the labour force of a Member State can still invoke that provision once that worker has acquired the nationality of the host Member State while retaining his Turkish nationality” (par. 41). 
parents to choose which nationality prevails ${ }^{32}$.

As in the previous case, the room which opens up for parties to choose, is a consequence, a by-product of another development, i.e. the principle of nondiscrimination. One could almost say that it is a 'collateral damage', in the same line as the freedom granted to businesses, under Centros and its progeny, to incorporate in any Member State while developing activities in other States, is a by-product of the freedom to provide services. True, the case law of the Court does not require Member States to abandon all ambition of regulating crossborder family relationships and to grant parties an unlimited autonomy to select the applicable law ${ }^{33}$. It remains that these developments pave the way for a greater flexibility which allows parties to manage their legal status as they see $\mathrm{fit}^{34}$.

7. It it one thing to describe with minutiae the extent to which the existing Regulations allow parties to choose the law to a given legal relationship. State of the art research should, however, go beyond this and also attempt to capture the extent to which choice possibilities are effectively used. This is particularly relevant since party autonomy is fairly new in international family relationships. It may take some time for practitioners to understand and master the various choice possibilities offered today by European law. These possibilities will also need to be studied in their interactions with other rules.

This task requires going beyond traditional desk research. In order to have a good overview of how practitioners work and adapt to new possibilities offered by the law, it is not enough to draw from one's experience, however broad it may be. Rather, one should attempt to engage in a wider exercise, based on facts. One possibility is to research case law. Court rulings will indeed provide indications of how often parties make use of the possibility to choose the law. This could work for some regulations. When parties choose the law applicable to their divorce in accordance with Article 5 of the Rome III Regulation, this may end up in court ${ }^{35}$. For other Regulations, it will be much more difficult to rely on case law. It is well known that succession cases are not often brought to courts. At least in continental Europe, succession matters rarely end up being dealt with in court. Hence, drawing from court cases will not allow to obtain a firm grasp of how much use is made of Article 22 of the Successions Regulation. A first step may be to explore the various newsletters and brochures published by specialized law firms, in order to discern whether and in which circumstances

32 For more details, see JiNSKE VERHELLEN, Het Belgisch IPR-Wetboek in familiezaken. Wetgevende doelstellingen getoetst aan de praktijk, Die Keure, 2012, at pp. 385-388.

33 As explained by J. MEEUSEN, 'Le droit international privé et le principe de non-discrimination', Collected Courses of the Hague Academy of International Law, volume 353, 2012, p. 127. According to Meeusen, the recent evolution of the case law does not lead to "la généralisation obligatoire, sur la base du principe de non-discrimination, de l'autonomie de la volonté en matière familiale pour les citoyens de l'Union résidant sur le territoire d'un autre Etat membre".

34 Outside the realm of European private international law, other developments also make it possible to take into account's parties' wish and expectations. See e.g. in relation to marriage and name, the explanations of J. VerHeLLEN, 'Lost in Nationality : Private International Law and Cultural Diversity', in Legal Approaches to Cultural Diversity (M.-CL. FoBLETS and N. YASSARI ed.), Hague Academy of International Law, 2013, (521), at pp. 567-571.

35 This assumes case law is duly reported and made available. This is not always the case. See for Belgium, G. VERSCHELDEN, "Empirisch familierechtelijk onderzoek in België : yes we can'”, Tijdschrift voor Familierecht, 2011, pp. 234-236 and G. VERSCHELDEN, "Pleidooi voor meer empirie in de familierechtswetenschap”, in Liber amicorum Boudewijn Bouckaert : vrank en vrij, Die Keure, 2012, pp. 403-423. 
practitioners advise their clients to make a choice of law ${ }^{36}$. This will, however, not prove sufficient to gain insight on how choice of law is actually used.

8. Other tools will, however, need to be deployed if one is to find out if and to which extent parties make use of the choice possibilities. This applies in particular when one looks at the various covert forms of party autonomy. Finding out how and when an individual relies on one of his nationalities in order to avoid the application of a given national law, requires sophisticated investigation methods. Social science could help. One could think of setting up interviews with seasoned practitioners and judges. This could compensate for the lack of central database recording all instances where, for example, a will includes an express choice of law ${ }^{37}$. Empirical research has only recently started in the field of international contracts ${ }^{38}$. Family law scholars should jump on the same train and brush up their empirical research skills, if they want to discover if and how the choice possibilities they analyze, are currently used in practice.

\section{Section 2 Reflecting upon the consequences of party autonomy}

9. Once a well-developed overview of instances of choice has been developed, one should also attempt to reflect upon the consequences of the freedom granted to individuals. Even if one lacks precise empirical data on the use, or lack thereof, of party autonomy in cross-border family relationships, this does not prevent from reflecting upon the possible consequences of such use.

Research questions are plentiful. One possible direction for further research is to look at the consequences of the multiplicity of choice possibilities in particular from the angle of coherence. As conceived under the current legal regime, a choice is expressed for a particular legal relationship and not for the whole series of questions which may arise in the course of an individual's life ${ }^{39}$. A citizen may choose a law to govern his/her succession. If he/she is married, the spouses may have chosen the law under which they may seek to divorce and possibly to claim maintenance. It may be that all these choices are devised globally, acting upon the advice of specialized counsel, taking into account the relationships between the various fields concerned ${ }^{40}$. In that case, the different

36 See e.g. the following brochure entitled 'At last... Napoleonic Succession Law Now Avoidable for Foreigners Living in France', published at www.blevinsfranks.com/News/BlevinsFranks/BlevinsFranksNews?ArticleID=684.

37 Such comprehensive research has been undertaken in the Netherlands in relation to marriage contracts. See recently, F.W.J.M. SCHOLS \& F. HOENS, "CNR-Huwelijksvoorwaardenonderzoek - deel II : verekkenbedingen en bijzondere facetten”, WPNR, 2014, (33), 43.

38 See S. Vogenauer, 'Regulatory Competition Through Choice of Contract Law and Choice of Forum in Europe : Theory and Evidence', (2013) 21 Eur. Rev. Priv. L., 13-78; S. VogenAuER and S. WeAtheriLl, 'The European Community's Competence for a Comprehensive Harmonisation of Contract Law : an Empirical Analysis”, (2005) 30 Eur. Rev. Priv. L., 821-837 and G. CuniBerTi, “The International Market for Contracts : the Most Attractive Contract Laws”, Northwestern J Intl Law \& Bus., 2014, vol. 34/3, pp. 455-517.

39 Compare with the system suggested by Carlier in 1990's - according to Carlier, parties could exercise an option and select the law applicable to their family relationships. In the draft Convention he put forward, Carlier contemplated a choice for the national law or the law of the habitual residence, which would apply to all questions belonging to the 'personal status' of the persons concerned (op. cit., pp. 391). In another part of his book, Carlier seemed, however, to accept the possibility that parties could select different laws for the various questions raised by their family relationships (op. cit., pp. 270).

40 See for an attempt to coordinate the various choice possibilities offered by European private international law instruments, e.g. C. Butruille-CARDEW and C. Preney, 'Articulation du Règlement Rome III avec les autres instruments : clauses de juridiction et loi applicable', AJ Famille, July 2012, pp. 385-389. 
choices expressed by the party /parties concerned will It is, however, far from excluded that such choice could happen in haphazard way, without much coordination $^{41}$.

One intriguing question is whether such uncoordinated choice could lead to difficulties for the person(s) concerned. One could think of possible contradictions between the national systems, if one and the same person has expressed a choice for different national law in different contexts ${ }^{42}$. Going further, one should also inquire whether such unfettered freedom leading to choice for multiple laws, does not raise the risk of unraveling the personal status and family relationships. Rules regulating these questions may be assumed to have been conceived within each Member State with a view to guarantee intrinsic coherence. Research should therefore attempt to find out whether, as has been claimed ${ }^{43}$, multiple choices may imperil the balance achieved within one national family law.

10. Looking further, one should also inquire if the recognition of party autonomy in cross-border family relationships will have any impact on other mechanisms of conflict of laws. Conflict of laws rules indeed are peculiar in that their application come with a series of technical devices intended to correct, qualify and/or extend their working. When applying a conflict of laws rule, one should for example inquire whether the law deemed to be applicable, should be understood as covering only the substantive provisions, or also include the conflict of laws rules of the law designated ${ }^{44}$. Until recently, these devices have worked with conflict of laws rules leaving no or only limited room for party choice in family relationships.

Two questions come to the mind when contemplating the consequences of allowing parties to choose the law governing family relationships. In the first place, one should examine how such greater choice possibility will affect the role of authorities called upon to apply the law. Although the status of conflict of laws rules may vary ${ }^{45}$, traditional conflict of laws thinking may require the court to apply these rules ex officio. In some jurisdictions, a distinction is made depending on the nature of the matters covered by conflict of laws rules. The greater recognition given to choice of law commands that the role of courts and other authorities be investigated. Giving parties more say on the applicable law may indeed require to scale down the role of courts and authorities when looking at cross-border relationships. This question need to be limited to the application by the judge of conflict of laws rules. It should also encompass the effects of a greater freedom to choose on the role of courts called upon to apply foreign law.

41 Any coordination should also include the tax consequences of certain choices.

42 This bears some resemblance with the difficulties raised by 'dépeçage' in cross-border contracts.

43 See e.g. M. FARGE, Le statut familial des étrangers en France : de la loi nationale à la loi de la résidence habituelle, L'Harmattan, 2003, pp. 627-628; K. MEZIOU, « Migrations et relations familiales », Collected Courses of the Hague Academy of International Law, volume 345, 2009, (13), 304-312. See also the observations of J. MEEUSEN, "Le droit international privé et le principe de non-discrimination”, Collected Courses of the Hague Academy of International Law, volume 353, 2012, (13), 128.

44 The technique of 'renvoi' has lost some of its relevance due to the unification of conflict of laws rules in various European instruments. It retains some value, as shown by Article 34 of the Succession Regulation.

45 As shown among others by T. DE BOER, "Facultative choice of law : the procedural status of choice-of-law rules and foreign law”, Collected Courses of the Hague Academy of International Law, volume 257, 1996, 223-427. 
Another classic device whose operation must be questioned in light of the wide recognition of party autonomy, is the public policy exception. If parties may choose the law, it must be questioned whether this will have an impact on the possibility for a State to refuse to apply the law chosen ${ }^{46}$. This question has already been debated in relation to polygamous marriages ${ }^{47}$. It needs to be reconsidered in view of the expansion of the realm of party autonomy.

11. Another area where further research is called for, relates to the consequences of party autonomy on the legal systems of Member States. Allowing parties to choose the law empowers them not only to express their preference for the law of their choice, but also to avoid the application of a legal system which does not meet their expectations. A German citizen residing in Spain could opt for the application of German law for his succession not only because of the various possibilities offered by German law - and in particular the possibility of agreeing with his heirs on how his succession will be divided through the mechanism of 'Erbverträge' - but also in order to avoid the application of Spanish law. This dual role of party choice becomes even clearer when a British citizen residing in France decides to subject his succession to English law : this choice may be given by the desire to avoid the application of forced heirship rules which are very strong under French law. Party choice resembles in that respect the 'voting with your feet' metaphor widely used by political scientists and economists to describe people's reaction to organizations they are dissatisfied with $^{48}$.

Viewing choice of law as an "easy exit option from inefficient law" 49 , it has been argued that in areas where parties are indeed given the possibility to select the applicable law, the freedom of choice may result, provided other features of the legal system allow for it, in a competition between legal system. The paradigm of regulatory competition implies that lawmakers will be forced to revise their laws in order to ensure that they offer an attractive product ${ }^{50}$.

12. This line of argument should be considered with due care in the various fields of family law where freedom of choice has been allowed. If persons living in a Member State are given the possibility to opt out of this State's law, one should investigate whether the exercise of party autonomy will exercise pressure on the States concerned to reassess their legislative policy ${ }^{51}$. If all

46 According to Carlier, the public policy exception keeps its role when a relationship is governed by the law chosen by parties, but its intervention is more limited (op. cit., pp. 377).

47 See e.g. the criticism voiced by Lagarde against Carlier's proposal to allow foreigners to choose the law of their country of origin : P. LAGARDE, 'La théorie de l'ordre public international face à la polygamie et à la répudiation. L'expérience française' in Nouveaux itinéraires en droit. Hommage à François Rigaux, Bruylant, 1993, at p. 276.

48 See e.g. A. O. HIRSCHMAN, Exit, Voice and Loyalty. Responses to Decline in Firms, Organizations and States, HUP, 1970, $176 \mathrm{p}$.

49 H.-B. SchäFER and K. Lantermann, 'Choice of Law from an Economic Perspective', in An Economic Analysis of Private International Law, J. BASEDOw et al. (ed.), Mohr, 2006, 95.

50 On the requirements for such competition to exist, see M.-E. KIENINGER, 'Competition between Legal Systems', in Max Planck Encyclopedia of European Private Law, J. BASEDOW et al. (eds.), OUP, 2012, 301-304.

51 According to Muir Watt, "in family law matters, the European version of the federal 'right to travel' introduces mobility - the market factor - into conflict of law. Free choice of a more liberal personal or family regime ... is accessible to individuals who are able to cross borders, as long as no particular link to the local community is required to create a relationship prohibited by the home law of the parties... [F]ree movement, whether between laws or courts, creates a market by empowering parties to arbitrage. It is up to the conflict of laws to regulate this market by introducing limits on the mobility of private actors in order to achieve a measure of 'juridical touchdown' when competition becomes distorted" (H. MUIR WATT, 'The role of the conflict of laws in European private law', in The 
British citizens living in France decide to opt out of French law, and choose English law to govern their succession, it may be wondered what effect this will have on French policy, in particular in relation to forced heirship rules ${ }^{52}$. At this stage, one can only guess whether allowing party choice will open Pandora's box. Experience in other contexts has shown that to some extent, States react to the pressure exerted by businesses shopping around for the best regime : following the Centros decision and its rich progeny which greatly opened the way for incorporation shopping, one witnessed a substantial migration of businesses to England, which in turn could explain the sudden urge of a number of States in continental Europe to simplify their corporate laws ${ }^{53}$. The fear that a similar phenomenon could also occur in family law has been voiced ${ }^{54}$.

It may not be easy to apply the model of competition between legal orders to the realm of family law. In contrast with incorporation choices made by businesses or choice of law in cross-border contracts, the impact of choices made by private individuals in matters of maintenance or divorce will not enjoy much visibility. How could the public at large know that their neighbors have been able to escape local law thanks to a choice of law? State agencies may not either have any information on such choices. Without such publicity, it may be wondered how States could react to 'exit' choices made by individuals. Even if some court cases reveal the existence of 'exit' choices and lawmakers are alerted, for example through parliamentary questions, attention should be paid to the incentive structure : what interest will lawmakers have in responding to the pressure and 'improving' their 'products'? When a State offers an attractive legal regime for incorporation of companies, this may lead to both direct and indirect benefits, such as additional tax revenue or even job creation. The question must be addressed whether a similar incentive exists in family law. Experience in other contexts has revealed that the hypothesis of regulatory competition should be approached with caution ${ }^{55}$. A similar line of research is needed which would test the assumptions of regulatory competition in the new fields conquered by party autonomy ${ }^{56}$.

Undoubtedly, if one finds out that there is indeed a direct or indirect effect on policies of States, this may raise the ghost of disappearing national autonomy and its impact on the democratic processes within Member States ${ }^{57}$. It will also

Cambridge Companion to European Private Law, CH. Twigg-FLESNER (ed.), CUP, 2010, 44-57, 56).

52 Bourdelois has argued that since reserved heirship is a fundamental policy in France, application may be made of the public policy exception found in Article 35 of the Succession Regulation to avoid the application of law chosen by the deceased if that law does not recognize any forced heirship. It is very interesting to note that she builds her argument on the notion of discrimination (B. BOURDELOIS, op. cit., at p. 143).

53 The claim has been researched with great nuance by W.-G. RINGE - see among other, 'Corporate Mobility in the European Union - A Flash in the Pan? An Empirical Study on the Success of Lawmaking and Regulatory Competition', Eur. Comp. \& Fin. L. Rev., 2013, 230-367. On the reforms undertaken in many EU countries, see Y. DE CORDT and J.-E. NAVEZ (ed.), La simplification du droit des sociétés privées dans les États membres de l'UE - Étude comparée des réformes entreprises dans le paysage sociétaire européen, Bruylant/L.G.D.J., 2014.

54 Commenting the possibility to choose the law offered by Article 22 of the Succession Regulation, Bourdelois writes "Introduire un choix de loi n'est donc pas qu'une modalité de désignation de la loi applicable : cela creuse les lézardes que les réformes récentes ont créées dans les fondements. A quand la ruine de l'édifice?” ( B. BouRDELOIs, op. cit., at p. 143).

55 See most notable S. Vogenauer, 'Regulatory Competition through Choice of Contract Law and Choice of Forum in Europe : Theory and Evidence', Eur. Rev. Priv. L., 2013, 13-78.

56 For a first, modest attempt, see P. WAUTELET, 'Autonomie de la volonté et concurrence régulatoire - le cas des relations familiales internationales', in Vers un statut européen de la famille? H. FULCHIRON and СH. BIDAU-GARON (ed.), Dalloz, 2014, 131-145.

57 The existence of very liberal rules of jurisdiction and a strong imperative to recognize foreign divorces under the 
again raise the question of the disappearance of national legal traditions. It is submitted, however, that the fear of feeding Euroscepticism should not lead to turning away from this question. On the contrary, shedding light on the real impact of party autonomy and the existence - or not - of a 'race to the bottom' will help feed the democratic debate. Thorough research leading to reasoned results is in any case better than mere phantasms feeding on unexplained assumptions.

13. Linked to the debate on regulatory competition, attention should also be paid to the effects of greater freedom on mandatory rules. Again, the experience garnered in the field of cross-border contracts puts the finger on an interesting question. Freedom of choice and mandatory rules indeed go hand in hand in cross-border contracts. Although such mandatory rules are certainly not confined to international contract law $^{58}$, the gradual acceptance of party autonomy in cross-border contracts has led courts to discover in their substantive laws certain rules which deserve to be applied no matter what law govern the relationship at hand. Opening the possibility for citizens to select the law applicable to some of their family relationships, may lead to a similar development. The question is therefore whether the recognition of party autonomy could or should foster the development of internationally mandatory rules in family law. In that respect, it is striking that while the Rome I and II Regulations expressly allow courts to apply their mandatory rules ${ }^{59}$, an equivalent provision cannot be found in the Succession Regulation, the Rome III Regulation nor in the Maintenance Regulation. This certainly calls for a thorough investigation.

\section{Section 3 Reflecting upon the limits of party autonomy}

14. Party autonomy has a long and sometimes troubled history. Its recognition as one of the cardinal principles of the legal regime of cross-border contracts did not come without challenges ${ }^{60}$. If the opposition did not succeed in challenging the very principle of party autonomy, it did manage to limit its scope. So it is that the possibility for parties to choose the law is never recognized without some limitation. Party autonomy is sometimes excluded or reduced ex ante this is most notable the case for consumers contracts ${ }^{61}$. When parties have the possibility to choose the applicable law, States have kept a back door open to

Brussels IIbis Regulation, has already led to a form of 'hidden' liberalization. As Meeusen wrote, "There is [...] a great paradox : the absence of substantive consensus results in a very liberal system which essentially obliges the host State to import family law concepts through the recognition of foreign judgments, while neither its national parliament nor the European Parliament never have had to approve such private international law rule, let alone such substantive concepts of family law" (J. MeEusen, 'Instrumentalisation of Private International Law in the European Union : Towards a European Conflicts Revolution?', Eur. J. Migration L., 2007, (287), at p. 304).

58 And may indeed be found in all fields of private law.

59 See Article 9 Rome I Regulation and Article 16 Rome II Regulation.

60 See most notably the crusade undertaken by Niboyet in the early decades of the 20th century to defeat the principle of party autonomy - e.g. J.-P. NiBOYET, "La théorie de l'autonomie de la volonté", Collected courses Hague Academy, 1927, I, vol. 16, 1-116 and J.-P. NIBOYET, Traité de droit international privé français, vol. V, Sirey, 1948, 4-36. More recently, see the renewed efforts by V. Heuzé, La règlementation française des contrats internationaux : étude critique des méthodes, GLN, 1990, 392 p.

61 Recent research has shown that consumers are protected against choice of law clauses in a very similar fashion in the EU and under US law, see G. RÜHL, "Party Autonomy in the Private International Law of Contracts. Transatlantic Convergence and Economic Efficiency”, in E. GotTSCHALK/R. MichaELs/G. RÜHL/J. vON HEIN (eds.), Conflict of Laws in a Globalized World, 153, 167-171 (2007). 
impose what they deem to be important regulatory concerns. This is usually done through so-called internationally mandatory rules, which limit party autonomy ex post. Another much discussed limitation which characterizes the current European regime arise out of a Westphalian concern to preserve States' monopoly on regulation : under the Rome I Regulation, the freedom of parties does not allow them to opt out of the law of States ${ }^{62}$.

These limitations have managed to achieve a balance between freedom and regulation. Since party autonomy in family law is to a large extent inspired by and even modeled on the regime for cross-border contracts, the question must be raised which limitations should be adopted for party choice in family law. The question is not only whether limitations are required, but also how they should be implemented.

15. This inquiry may be started with an assessment of how EU Regulations allowing parties to select the applicable law, already limit such choice. The most interesting limitation arises out of the fact that the possibility to choose the law is not an open one. Contrary to what is accepted for cross-border contracts ${ }^{63}$ and cross-border torts ${ }^{64}$, the choice of law in family matters is only possible for a selected number of legal systems. The Preamble of the Rome III Regulation makes it clear that the possibility to choose the law has only been accepted provided a choice is made for a law "with which [the spouses] have a close connection" ${ }^{65}$. The Preamble of the Succession Regulation likewise refers to the

62 During the process which led to the revision of the Rome Convention, it was suggested to allow a choice for another system than the law of a State. The original proposal for the Rome I Regulation made it possible for parties to choose "the principles and rules of the substantive law of contract recognised internationally or in the Community", Art. 3(2) original Proposal for a Regulation, COM (2005) 650 final 6. This led to a rich discussion (e.g. W.-H. RoTH, „Zur Wählbarkeit nichtstaatlichen Rechts“, in H.-P MANSEL/R. HAusmann/C. KOHLER/H. KronKE/T. PfeIfFer (eds.), Festschrift für Erik Jayme 757-772 (2004); J. KONDRING, „Nichtstaatliches Recht als Vertragsstatut vor staatlichen Gerichten - oder: Privatkodifikationen in der Abseitsfalle?“, 27 IPRax 241-245 (2007)). It was not entirely clear whether the language suggested by the Commission would have allowed a direct reference by the parties to the rules of international law. The question has been settled with the adoption of the Rome I Regulation, which clearly confirms that a choice can only be made for municipal law. Recital 13 of the Preamble, however, allows parties to incorporate "by reference into their contract a non-State body of law or an international convention." On this compromise reached between the Council and the European Parliament, see R. PLENDER/M. WILDERSPIN, The European Private International Law of Obligations 137-138, para. 6-012 (2009). Therefore, if parties, e.g., made a choice for international law, this reference to international law would probably only lead to the "incorporation" of the rules of international law in the contract, see, e.g., F. Ferrari, Comment Art. 27 EGBGB, in F. Ferrari/E.-M. KIENINGER/P. MANKOWSKi/K. OTTE/I. SAENGER/A. StAudinger (eds.), Internationales Vertragsrecht 12, para. 19 (2007). In other words, such a choice would not prevent the application of the mandatory provisions of the national law which would be applicable to the contract absent a choice of law by the parties. Outside the realm of the Rome I Regulation, there is less difficulty to express a choice for something else than municipal law. This is the case for the Inter-American Convention signed in Mexico in 1994, whose provisions appear to make it possible to choose another law than that of a State - This results from a combined reading of Articles 1, 7 and 9; see in general F. K. JUENGER, "The Inter-American Convention on the Law Applicable to International Contracts: Some Highlights and Comparisons", 42 AJCL 381, 392 (1994). Juenger wrote that "the parties are free to stipulate to the general principles of international commercial law." See in general R. MichaELS, "The Re-Statement of Non-State Law: The State, Choice of Law and the Challenge from Global Legal Pluralism”, 51 Wayne L. Rev. 215 (2005).

63 Under Art. 3 of the Rome I Regulation, it is accepted that parties may select the law of a country which bears otherwise no connection with their contract. See e.g. L. STRIKWERDA, De overeenkomst in het ipr, Maklu, 2010, p. 116, par. 197.

64 Art. 14 Rome II. As with the Rome I Regulation, it is accepted that the choice expressed under Article 14 of the Rome II Regulation need not bear any connection to the relationship at hand, see e.g. E. LOQUIN, "La règle de conflit générale en matière de délit dans le règlement du 11 juillet 2007 (Rome II)", in Le Règlement communautaire 'Rome II' sur la loi applicable aux obligations non contractuelles, S. CORNELOUP \& N. JOUBERT (eds.), Litec, 2008, at p. 52-53.

65 Recital 14 Preamble Rome III Regulation. 
fact that the possibility to choose the law "should be limited to the law of a State of their nationality in order to ensure a connection between the deceased and the law chosen..."66.

These limitations act as important constraints on the freedom enjoyed by parties ${ }^{67}$. From a conceptual point of view, they could even justify using another terminology to refer to the choice : instead of talking about party autonomy, one should maybe talk about 'party option' - or optio iuris - to designate the possibility to choose the law. Going further, these limitations may even be taken to mean that when parties select the applicable law, this is not a real choice of law, on equal footing with determination by the judge on the basis of a conflict of laws rule ${ }^{68}$.

These limitations already call for some investigation. One could for example inquire why party autonomy is not recognized alongside identical lines in all fields of family law. That the choice under the Succession Regulation is limited to the law of the nationality of the person concerned, while a choice may be expressed in favor of another law under another Regulation, is intriguing. Likewise, one could ask why spouses are not afforded the possibility to choose the court in divorce matters, while a choice of court is possible, to a limited extent, in maintenance disputes. It must be asked whether there is room for several distinct brands of party autonomy depending on the subject matter concerned. It may be indeed that party autonomy need not to be recognized alongside identical lines in all fields of family law. This should at least be investigated as a first step in defining the outer limits within which parties may exercise their freedom. At the same time, attention should be paid to the interactions between the choice of law and the regime dealing with multiple nationalities.

16. When looking at possibles limitations of party autonomy in international family law, attention should also be paid to the consequences of party autonomy on the protection of parties. The paradigm of choice in international private relationships, can be traced back to the field of international contracts. It is in relation to cross-border contracts that the idea of choice by parties arose. In contractual relationships, it may be taken for granted that parties have similar bargaining power. This explains why for a long time, it was not thought useful to introduce limitations aimed at protecting categories of parties. It is only fairly recently that new rules have been developed to limit the exercise of party

66 Recital 38 Preamble Succession Regulation.

67 One may add that in matters of divorce, Article 10 of the Rome III Regulation prohibits the application of the law chosen by the spouses if it does not make any provision for divorce or does not grant one of the spouses "equal access to divorce or legal separation on grounds of their sex". This limitation translates a substantive policy objective, i.e. guarantee the equality between spouses.

68 Leading authors have indeed argued that the choice recognized in various contexts, does not amount to party autonomy. Rather, the choice possibility is explained as a method used by the legislator to overcome the traditional opposition between the application of the law of the nationality and the law of the domicile or habitual residence : in many cases, these two connecting factors may prove equally relevant to determine the applicable law. Instead of making an abstract choice between the two, the law leaves it to the persons concerned to choose. See e.g. Audit/d'Avout, Droit international privé, 7th ed., 2013, p. 199, nr. 211 : "Il ne s'agit nullement d'étendre en matière personnelle l'autonomie de la volonté telle qu'elle est comprise en matière contractuelle, où elle se fonde sur les nécessités du commerce international [...]; mais seulement de permettre aux intéressés de résoudre eux-mêmes un conflit auquel ils se trouvent spontanément soumis et dans lequel aucune loi ne jouit $a$ priori d'un titre à s'appliquer supérieur à l'autre”. Carlier on the other hand sees party autonomy in family matters as a true conflict-of-laws rule (op. cit., pp. 255-257), par. 237-238). 
autonomy in relation to certain contracts ${ }^{69}$. If one leaves these developments aside, the principle remains that parties should be left to cope with the consequences of their freely assumed choice.

This assumption may not hold entirely in family relationships ${ }^{70}$. The balance of power between spouses or between parents and children may be very different from that holding between parties to a contract. In family relationships there may be a lack of equality among partners, information asymmetry or, worse, a situation where one party imposes a choice on another. Emotional considerations could also play an important role. It may not be assumed that discussions will proceed at arm's length. On the contrary, one could even start from the assumption that parties need to be protected. Recognition of party autonomy hence calls for the adoption of safeguards in order to guarantee that the choice is based on a true consent ${ }^{71}$.

The Rome III Regulation has attempted to tackle this issue. Article 6 makes it possible for a spouse to draw from another law than the one chosen by parties, to demonstrate that he/she did not actually consent to an agreement on choice of law. Article 7 provides additional rules dictating that the agreement between spouses meets certain formal requirements. These rules are supplemented by indications to be found in the Preamble of the Rome III Regulation, which insists on the information to be provided to spouses before they agree on the law applicable to their divorce ${ }^{72}$. It is, however, widely accepted that these safeguards, which are directly inspired by equivalent provisions found in the Rome I Regulation are insufficient to guarantee that spouses are in all cases aware of the importance of and the consequences of a choice of law agreement. In family relationships, one cannot start from the premise that parties are equal and have equal access to relevant information. Further work is therefore needed to define standards ensuring that choice of law by parties is based on true, informed consent. This could be done by comparing existing standards to be found in substantive law. The goal should be to design a legal provision ensuring that fairness ruled when parties chose a law.

17. Another area where research is needed, relates to the areas where party choice if allowed. Until now, we have witnessed a steady progression of party choice : starting with divorce proceedings, party autonomy has conquered other fields of family relationships. The principle of party choice has not raised too many difficulties in matters of succession and matrimonial assets. In domestic matters, these areas already make it possible for individuals to exercise some

69 See e.g. Article 6 and 8 of the Rome I Regulation (in relation consumer and employment contracts).

70 As noted Boele-Woelki noted in 2007, “Terwijl de zwakkere positie van de consument en werknemer in het IPR is verdisconteerd nemen de familierechtelijke Verordeningsvoorstellen de gelijkheid van partijen tot uitgangspunt. Maar is dat wel gerechtvardigd? Is er in een familierechtelijke verhouding vaak niet ook een zwakkere partij? Kunnen verschillende economische omstandigheden niet tot ongelijkheid leiden? Zijn onderhoudsgerechtigden niet zelden vrouwen die vanwege de zorg voor kinderen financieel afhankelijk zijn van hun gewezen partner?” (K. BOELE WOELKI, “Forum- en rechtskeuze in de nieuwe familierechtelijke verordeningen”, FJR 2007, 297).

71 See already Article 9 of the draft Convention on the law applicable to personal status matters, suggested by Carlier (op. cit., p. 392).

72 According to Recital 17, spouses should have "access to up-to-date information concerning the essential aspects of national and Union law and of the procedures governing divorce and legal separation”. Recital 18 indicates that the "informed choice of both spouses is a basic principle of this Regulation". The same Recital notes that "Each spouse should know exactly what are the legal and social implications of the choice of applicable law" and that "The possibility of choosing the applicable law by common agreement should be without prejudice to the rights of, and equal opportunities for, the two spouse s”. 
form of control over their relationships. Things are different for divorce : here, the resistance has been fiercer and may help explain why the Rome III Regulation could only become reality through enhanced cooperation.

Although there are not immediate plans within the EU to venture in other areas of family law, the question must be addressed : if the Member States ever agree that common conflict of laws rules are needed to deal with cross-border marriages or the establishment of parent-children relationships, will there be any room for party choice? Looking at the current regimes in Member States, it does not seem that party autonomy stands any chance of being accepted ${ }^{73}$. No Member State leaves any room for party choice in these matters. Further, the creation of a marital link or of a parent-child relationship seem to be much less amenable to party choice even in domestic matters. This is the realm of imperative regulation. At the very least, however, the question should be addressed why these areas should be treated differently from matrimonial property or divorce. If indeed party autonomy is deemed not to be welcome in these areas, this may say much about the visage of party autonomy in areas where it is welcomed.

\section{By way of conclusion}

18. The recent and rapid rise of party autonomy as a new paradigm for crossborder family relationships offers new possibilities to smoothen the regulations of these relationships, which are often torn between States' conflicting (substantive and private international law) policies. The advent of party autonomy in international family law also opens up exciting times for researchers in international family law. The recognition of party choice brings new ground for research. Questions indeed abound, which may keep researchers busy for some time.

Taken at its extreme, the possibility for citizens to opt out of a legal system and to choose another one, must be appraised in the light of the relationship between a State and its citizens. What does it mean to be a citizen of a State and residing somewhere, if one may freely opt for the legislation of another State? Does this lead to the 'commodification' of the relationship between a State and its citizen?

In the long run, research in these directions should hopefully help draw the lines of a general theory and legal framework for party autonomy in cross-border family relationships. One should hope that research of this kind will help develop party autonomy in something proper for family relationships, far from the simplistic copy-paste attitude which has prevailed until now. It may well be that the end result will not bear much resemblance to party autonomy as it exists in cross-border contracts and other commercial relationships. As such, this would only signal that private international law may no longer be able to offer one, comprehensive theory of party autonomy.

Further research will hopefully also be able to answer the question whether there is a specific EU dimension to party autonomy. In view of the fact that party

73 In this sense, B. BOURDELOIS, op. cit., at p. 143. 
autonomy has also gained increased recognition outside the EU (witness recent Conventions adopted by the Hague Conference on private international law ${ }^{74}$ or national statutes ${ }^{75}$ ), it must be asked whether there is a special EU dimension to party autonomy in family relationships. This could be the case if the very extensive mobility afforded to individuals within the EU, requires that party autonomy be recognized in a distinctive way. 